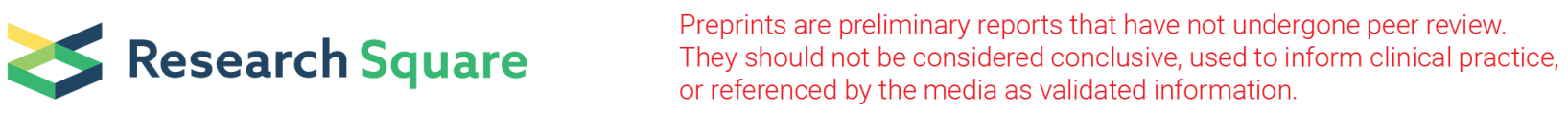

\title{
Effect of Urbanization on the Dynamics of Ecosystem Services: An Analysis for Decision Making in Kolkata Urban Agglomeration
}

Subhasis Das

Narajole Raj College

Pravat Kumar Shit

Raja Narendra Lal Khan Women's College

Biswajit Bera

Sidho-Kanho-Birsha University

Partha Pratim Adhikary ( $\triangle$ Partha.Adhikary@icar.gov.in )

Indian Institute of Water Management https://orcid.org/0000-0001-9292-8401

\section{Research Article}

Keywords: CA-Markov model, Ecosystem service value (ESV), Land use/land cover (LULC), Scenario analysis for ESV, Urban expansion

Posted Date: February 15th, 2022

DOI: https://doi.org/10.21203/rs.3.rs-1326859/v1

License: (c) (1) This work is licensed under a Creative Commons Attribution 4.0 International License. Read Full License 


\section{Abstract}

The structural strength and functional diversity of ecosystems were maintained by natural process, where the living organisms interact with their physical environment and exchange materials between them. Land use and land cover change exert significant impact on ecosystem services and their values, especially in the urban agglomerations. Kolkata urban agglomeration of India has been selected to determine the causes in changes of ecosystem services under present and projected land use land cover scenario. Land use land cover maps of 1990, 2000, 2010 and 2020 were prepared by support vector machine method, using LANDSAT satellite imageries and projected maps were produced with the help of CA-Markov model. Built-up land was increased by $65.39 \%$ during $1990-2020$ and it will be increased by $76.88 \%$ during the period $1990-2040$. Built-up lands are mainly encroaching crop lands and wetlands. The ecosystem service value will be decreased from $\$ 38486.49$ during 1990 to $\$ 28060.79$ during 2040 . The rate of change of ecosystem service value was $-27.09 \%$ during the same period. In Kolkata urban agglomeration, area under very low ecosystem service value will be increased from 16.60 to $58.88 \%$ during 1990-2040; whereas, the area coverage of very high ecosystem service value will be decreased from 2.69 to $2.35 \%$ during the same period. Water supply contributed highest ecosystem service value followed by disturbance regulation and nutrient cycling; whereas, lacking in soil formation, pollination and biological control services contributed lowest. The study will contribute for decision making process in sustainable management of natural resources and also provide some useful guidelines for the improvement of ecological quality in the study landscape.

\section{Introduction}

The structure and functions of ecosystem services were maintained by the interaction of living organisms with their physical environment and exchanging energy and materials between them (Chapin et al., 2012). The condition or quality of an ecosystem is measured with the aid of a set of ecological processes, which is related to both the system's ecological condition and its capacity to support ecosystem services. Ecosystem services (ESs) make valuable contribution not only for human wellbeing (de Groot et al., 2012; Das and Das 2019; Daily, 1997; MEA, 2005) but also for living organisms, therefore appropriate services of ecosystem components should be provided for them as well (Fisher et al., 2009; Costanza et al., 1997). Ecosystem Service Values (ESVs) are the values assigned to goods and services derived from ecological processes and can be used to assess the impact of anthropogenic activities on different ecosystems (MEA, 2005; Adekola et al., 2015); analysed environmental-human development interactions to enhance sustainable management of natural resource (Braat and de Groot, 2012; Potschin and Haines-Young, 2013). The evaluation and assessment of ESs has grown in importance as it can help cost-benefit analyses and decision making by incorporating both negative and positive effects of human development activities, such as Land Use and Land Cover (LULC) change on diverse ecosystems (Sannigrahi et al., 2020; Wang et al., 2018, 2019).

Expansion of urban area is one of the driving forces responsible for massive changes of ecological condition (Li et al., 2012; Aronson et al., 2014) and loss of natural capitals (Huang and Zhao, 2016). Population explosion and related infrastructure development are very common phenomena in urban area, which changes the LULC pattern (Gao et al., 2017). As a result, natural ecosystems are transformed to human-nature ecosystems, and destroy the ecosystem structureand functions (Shao et al., 2017; Wang et al., 2017). The environmental sustainability and regenerating capacity are under great threats due to loss of water bodies and vegetation cover within urban space (Keshtkar et al., 2017). It may increase temperature in urban areas and causes urban heat island effect (Manoli et al., 2019), urban flood effect (Gupta, 2002) and decline or shifts of ESs (Richards et al., 2020; Das and Das, 2019; Bohnet and Pert, 2010).

Investigations of ESVs are very common and popular among the researchers around the world (Liu et al., 2020; Li et al., 2017; Odgaard et al., 2017; Song, 2018). Many researchers (Danz et al., 2007; Robards et al., 2011) have emphasized that how human activities lead to changes of ESs. The urbanization process continuously converts the natural capitals; thus, it is very harmful for ecosystem functions (Wang et al., 2019). Currently, a large number of research articles have analysed the impacts of urbanization on ecosystem services from their own perspective. Das and Das (2019) observed that rapid urbanization changes the urban ESs. Richards at al., (2020) established that rapid urbanization causes to shift of ESs. Thus, assessment as well as estimation of the loss of ESs due to continuous urban expansion contributes significantly for future planning and sustainable urban development at regional scales.

Kolkata Urban Agglomeration (KUA), one of the many mega urban agglomerations of the world, is experiencing a rapid change in LULC because of its urban expansion. It leads to rapid decline of ecological environment of the region and thus deteriorated the ecosystem services (Mukherjee, 2012). Monitoring of spatial and temporal change of ESVs in KUA will help the planners and decision makers to adopt appropriate strategies for betterment of the standard of living of the people living there. The future change of ESVs will have direct repercussion with the LULC changes and indirectly affect the life of common people. Keeping these points in mind, the objectives 
of this study were (1) to map the spatial and temporal patterns of LULC change in KUA from 1990 to 2020 and their projection up to 2040; (2) to assess and predict the dynamics of ESV from 1990 to 2040 and highlights the ecosystem services which are most vulnerable; and (3) to provide road map for promoting economic development through balanced management of ESV.

\section{Materials And Methods}

\subsection{Study area}

The Kolkata city is located by the side of east and west bank of River Hooghly (Ganges Delta). The business, commercial, and financial activities in eastern and north-eastern India were mainly controlled by the city Kolkata. But, the word 'city', in relation to Kolkata, is not an officially recognised term; however, it is popular and used when referred to describe Kolkata Urban Agglomeration (KUA). The KUA includes both rural and urban areas of approximately $1886.67 \mathrm{~km}^{2}$, extends between $22^{\circ} 0^{\prime} 19^{\prime \prime} \mathrm{N}$ to $23^{\circ} 0^{\prime} 01^{\prime \prime} \mathrm{N}$ and $88^{\circ} 0^{\prime} 04^{\prime \prime} \mathrm{E}$ to $88^{\circ} 0^{\prime} 33^{\prime \prime} \mathrm{E}$ (Fig. 1). The KUA has five local Governments; however, the overall management, development and plan formulation of the area was maintained by Kolkata Metropolitan Development Authority (KMDA). It is also the third most populous city in India and 8th largest urban agglomeration in the world, with total population of approximately 14.11 million (Census of India, 2011). The population density has been increased by nearly 90.24\% from 1901 to 2011. The KUA has been formed with 3 municipal corporations (Howrah, Kolkata and Chandan Nagar), 38 municipalities, 77 non-municipal urban towns, 16 outgrowths and 445 rural villages. The region is experiencing rapid LULC changes and facing population pressure on natural resources, socio-economic challenges and deteriorating ecosystem services (Mukherjee, 2012).

\subsection{LULC classification and change detection}

Historical LULC data were used to map the dynamics of LULC in KUA. The LULC data includes eight satellite images (Landsat 5+TM, Landsat 7+ETM, Landsat 8+OLI) (path-row/ 138-44 \& 138-45) for the years 1990, 2000, 2010 and 2020, which were downloaded from the website https://earthexplorer.usgs.gov. We have classified the LULC with the help of support vector machine (SVM) tool. The radial basis function kernel-based learning model, which is fixed in ENVI 5.3 software, was used for SVM classification to tackle the issues of binary classification (Wijaya et al., 2008). It utilizes hyper planes that augment the edges between the data points, which is called support vector (Vapnik, 1998). A proper kernel function was provided in SVM arrangement to make precise hyperplanes, which lessens the error (Wijaya et al., 2008).

The SVM algorithm is depending on four parameters - the kernel width gamma ( $\mathrm{Y})$, the penalty parameter (C), the quantity of pyramids levels to utilize, and threshold value of the classification probability. The classification threshold probability is the most important component among these (Keshtkar et al., 2017). To sort-list the pixels into a single class, zero value has been allotted as the threshold. From that point onward, for the pyramid factor, once more, a value of zero has been allocated, which measure the picture at its full resolution. The reverse of the quantity of bands has been set automatically for the value of gamma. The following formula can express the radial basis kernel technique based SVM algorithm.

$K\left(x_{i}, x_{j}\right)=e^{\left(-y\left(x_{i}, x_{j}\right)^{2}\right.}, \gamma>0$

Where $x_{i}$ and $x_{j}$ denotes vector features in the input space, and $y$ is the width of the kernel function.

In the present study, supervised image classification and visual interpretation were combined for the preparation of LULC map where the classification scheme of Roy et al. (2015) was used. The prepared seventeen LULC classes were reclassified into six categories: river, vegetation, wetland, cropland, built-up land and bare land. The accuracy assessment is an essential part of the LULC change mapping, because it validates LULC map with ground (Rwanga and Ndambuki, 2017). For this purpose, 140 training points of each LULC types (total 840 points) were obtained from field survey to validate the LULC types (Elkhrachy, 2015). The value of kappa coefficient determined the overall classification accuracy.

Using the LULC maps for the years 1990, 2000, 2010, 2020, 2030 and 2040, the spatio-temporal dynamics and change of LULC were assessed for five decadal periods i.e. 1990-2000, 2000-2010, 2010-2020, 2020-2030 and 2030-2040 with the help of following equation:

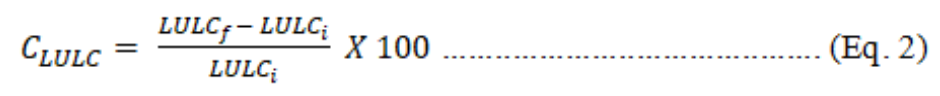


Where, $\mathrm{C}_{\mathrm{LULC}}$ is the decadal change of a particular LULC in per cent, LULC $\mathrm{f}_{\mathrm{f}}$ is the LULC at the end of the decade and LULC is the LULC at the start of the decade.

\subsection{LULC prediction using CA-Markov model}

LULC maps for the years 1990, 2000, 2010 and 2020 were prepared with the help of GIS and remote sensing techniques. Then, the LULC for the years 2030 and 2040 was predicted using CA-Markov model. The Markov model is a very popular technique used to calculate transitional probability of LULC types within observed time period (Guan et al., 2011; Lou et al., 2014; Shafizadeh and Helbich, 2013). The transitional probability means the probability of change of land cover type (pixels) in future. It expresses as transitional probability matrix if time $t_{0}$ changes to another land cover type in the time $t_{1}$. Thus, the technique is helpful to predict LULC scenario but cannot gives spatial information. The combination of Markov model and Cellular Automata (CA-Markov) simulate LULC scenario and gives spatial information with projected map (Sang et al., 2011). The LULC change predicting model was constructed using IDRISI software to explore the spatial patterns of projected LULC scenario. We have used LULC 1990 map as a base map, further used to determine LULC probability and project LULC patterns. This involves three steps. (1) Computation of transitional probability matrix in Markov model based on LULC map 1990 and 2020. (2) Computation of CA filter in CA-Markov model, where we have used $5 \times 5$ pixels contiguity as filter standard factor and kept the number of cellular automata interactions as 10. It measured the state change of the cells by considering the distance between neighbour and cell. (3) Finally, LULC change prediction map of 2030 has been projected and the same procedure was applied to project the LULC change prediction map of 2040.

\subsection{Assessment of ecosystem service value}

\subsubsection{Estimation and prediction of ESVs}

LULC change affects the structure and function of ecosystem, which play a key role in maintaining ecosystem services (Zhange and Gao, 2016). The principals and methods about the value assessment of ESs was analysed by Costanza et al. (1997). They computed global coefficient value for 17 ecosystem services of different LULC types. Recently, Costanza (2014) has modified these values and for Asian countries Xie et al. (2008) and Ye et al. (2011) have given coefficient values to calculate ESV. In the present study we adopted these coefficient values for six LULC types (river, vegetation, wetland, cropland, built up land and bare land) and modified for our need. For the purpose of estimation of ESV, study area has been sub-divided into $1 \mathrm{~km} \times 1 \mathrm{~km}$ grids and then the ESVs of different LULC types within each grid were measured. The detail description of adopted coefficient value is given in Table 1.

Table 1

ESV coefficients (US\$ ha ${ }^{-1} \mathrm{yr}^{-1}$ ) used in KMA for calculation of ESVs

\begin{tabular}{|lllllll|}
\hline Ecosystem service & River & Vegetation & Wetland & Cropland & Fallow land & Built-up land \\
\hline Gas regulation & 0 & 0 & 140 & 41 & 28.6 & 0 \\
\hline Climate regulation & 0 & 150.8 & 4.55 & 55.2 & 28.6 & 0 \\
\hline Water regulation & 7.97 & 5.12 & 19.91 & 43.8 & 15.4 & 0 \\
\hline Soil formation & 0 & 492.2 & 0 & 83.6 & 37.4 & 4.4 \\
\hline Waste treatment & 700.39 & 91.6 & 4.55 & 79.1 & 57.2 & 0 \\
\hline Biodiversity Maintenance & 0 & 18.78 & 320.3 & 50.6 & 87.9 & 74.7 \\
\hline Food production & 43.24 & 45.52 & 269.7 & 56.9 & 4.4 & 2.2 \\
\hline Raw materials Provision & 0 & 145.7 & 111.5 & 22.2 & 8.79 & 0 \\
\hline Recreation and cultural, and aesthetics & 242.4 & 71.69 & 1533 & 9.67 & 52.8 & 2.2 \\
\hline Total & 994 & 1021 & 2403 & 442 & 321 & 83.5 \\
\hline
\end{tabular}

We estimated the ESV from the year 1990 to 2020 based on the LULC map and predicted ESV for 2030 and 2040 based on the projected LULC map. The following equations were applied to calculate ESV for LULC types, LULC functions and total ESV, which were used in the adopted model for the study area. 
$E S V_{k}=\sum_{k}\left(A_{k} \times V C_{k j}\right)$

$E S V_{t}=\sum_{k} \sum_{f}\left(A_{k} \times V C_{k f}\right)$

Where $\mathrm{ESV}_{f}, \mathrm{ESV}_{k}$ and $\mathrm{ESV}_{t}$ represents ecosystem service value of LULC function $f$, ecosystem service value of LULC type $k$, and total ecosystem service value, respectively; $\mathrm{A}_{k}$ represents the area $\left(\mathrm{km}^{2}\right)$ for land use type $(k) ; \mathrm{VC}_{k f}$ is the coefficient value (US $\left.\$ / \mathrm{km}^{2} / \mathrm{year}\right)$ for land use type $(k)$ and function $(f)$.

\subsubsection{Change rate of ESV}

We have analysed grid-wise change rate of ESV to know the spatial locations where ESV has declined rapidly. It was calculated using the following equation:

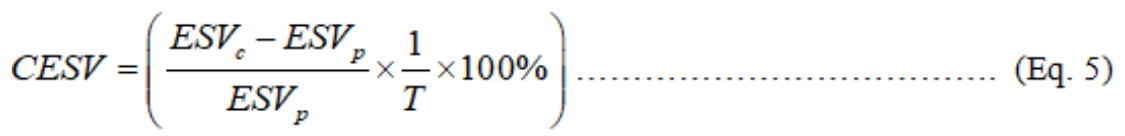

Where, CESV means change rate of ESV; $\mathrm{ESV}_{\mathrm{c}}$ and $\mathrm{ESV}_{\mathrm{p}}$ represents $\mathrm{ESV}$ for current year and previous year and T represent time period.

\section{Result}

\subsection{Model validation}

Firstly, we have validated LULC maps and after that we have validated actual and predicated ESV. The present LULC map of 2020 has been validated with training samples collected from field observation. In that case, we have collected 140 sample data for each LULC type, where kappa coefficient value was more than 86\%. Previous LULC maps of 1990, 2000 and 2010 were validated based on Google Earth training data and earlier literature study and found fit for presentation. Secondly, we have prepared predicted LULC map for the year of 2020 using CA-Markov model and also predicted ESV for that year. Actual ESV for the year 2020 and predicted ESV have been validated by plotting with 1:1 line and calculating $R^{2}$, Nash Sutcliffe Efficiency (NSE) (Nash and Sutcliffe 1970), RMSE, MAE and Index of Agreement (Al) values (Fig. 2). The validation result indicated that there was good agreement between observed and predicted ESV with R2, NSE and Al values was $0.95,0.952$ and 0.988 , respectively. The error components were also very low as the value of RMSE and MAE were 5.346 and 4.361 , respectively.

\subsection{LULC change analysis during $1990-2040$}

Six LULC types covering KUA for the years 1990, 2000, 2010, 2020, 2030 and 2040 were identified as (1) river, (2) vegetation, (3) wetland, (4) cropland, (5) built-up land, and (6) bare land. The spatial distribution maps of all the LULC types for six different years are presented in Fig. 3. The study revealed that during 1990 water body and wetlands covered significant area of KUA (about 32.53\%) and will be decreased to $25.82 \%$ during 2040. The spatial extent of all the LULC types was reduced during 1990-2040, except for built-up land (Table 2). Fig. 3 showed that expansion of built-up land mainly engulfed croplands, wetlands and vegetation cover area. The present study also exercised decadal rate of change of different LULC types. River, vegetation, wetlands, cropland and bare land changed negatively, whereas the built-up land changed positively (Table 3). Highest average negative rate of change was observed for croplands. The cropland was decreased by $-14.71 \%,-11.54 \%,-13.24 \%,-4.81 \%$ and $-0.50 \%$, respectively during the periods $1990-2000$, $2000-2010,2010-2020,2020-2030$ and $2030-2040$. During the same period, the rate of change of built-up land was always positive. The rate of change for built-up land was $25.51 \%, 17.88 \%, 11.79 \%, 5.34 \%$ and $1.52 \%$ during the periods $1990-2000,2000-$ 2010, $2010-2020,2020-2030$ and $2030-2040$, respectively. The wetlands were also significantly changed, $-5.26 \%,-13.67 \%,-9.04 \%$, $-6.68 \%$ and $-1.87 \%$ during the periods $1990-2000,2000-2010,2010-2020,2020-2030$ and $2030-2040$, respectively (Table 3). This information indicates that increased built-up land is closely linked to conversion of wetlands and croplands in the study area. The negative rate of change for river, vegetation and bare land was low between the observed periods. 
Table 2

Summary statistics of classified and simulated LULC dynamics in KMA from $1990-2040$

\begin{tabular}{|c|c|c|c|c|c|c|c|c|c|c|c|c|}
\hline \multirow[t]{3}{*}{ LULC types } & \multicolumn{8}{|c|}{ Classified area } & \multicolumn{4}{|c|}{ Simulated area } \\
\hline & \multicolumn{2}{|l|}{1990} & \multicolumn{2}{|l|}{2000} & \multicolumn{2}{|l|}{2010} & \multicolumn{2}{|l|}{2020} & \multicolumn{2}{|l|}{2030} & \multicolumn{2}{|l|}{2040} \\
\hline & $\mathrm{km}^{2}$ & $\%$ & $\mathrm{~km}^{2}$ & $\%$ & $\mathrm{~km}^{2}$ & $\%$ & $\mathrm{~km}^{2}$ & $\%$ & $\mathrm{~km}^{2}$ & $\%$ & $\mathrm{~km}^{2}$ & $\%$ \\
\hline River & 60.01 & 3.35 & 56.49 & 3.15 & 55.73 & 3.11 & 53.59 & 2.99 & 51.26 & 2.86 & 49.41 & 2.76 \\
\hline Vegetation & 395.21 & 22.06 & 378.41 & 21.12 & 354.49 & 19.79 & 338.52 & 18.90 & 331.58 & 18.51 & 326.05 & 18.20 \\
\hline Wetland & 127.71 & 7.13 & 120.89 & 6.75 & 104.36 & 5.83 & 94.93 & 5.30 & 88.59 & 4.95 & 86.94 & 4.85 \\
\hline Cropland & 505.73 & 28.23 & 431.33 & 24.08 & 381.56 & 21.30 & 331.05 & 18.48 & 315.11 & 17.59 & 313.54 & 17.50 \\
\hline Built-up & 450.86 & 25.17 & 565.87 & 31.59 & 667.03 & 37.23 & 745.69 & 41.63 & 785.53 & 43.85 & 797.49 & 44.52 \\
\hline Bare land & 251.89 & 14.06 & 238.42 & 13.31 & 228.24 & 12.74 & 227.63 & 12.71 & 219.34 & 12.24 & 217.98 & 12.17 \\
\hline
\end{tabular}

Table 3

Decadal change of LULC in KMA starting from 1990 to 2040

\begin{tabular}{|c|c|c|c|c|c|c|c|c|c|c|}
\hline \multirow[t]{2}{*}{ LULC types } & \multicolumn{2}{|c|}{$1990-2000$} & \multicolumn{2}{|c|}{$2000-2010$} & \multicolumn{2}{|c|}{$2010-2020$} & \multicolumn{2}{|c|}{$2020-2030$} & \multicolumn{2}{|c|}{$2030-2040$} \\
\hline & $\mathrm{km}^{2}$ & $\%$ & $\mathrm{~km}^{2}$ & $\%$ & $\mathrm{~km}^{2}$ & $\%$ & $\mathrm{~km}^{2}$ & $\%$ & $\mathrm{~km}^{2}$ & $\%$ \\
\hline River & -3.52 & -5.87 & -0.76 & -1.35 & -2.14 & -3.83 & -2.33 & -4.36 & -1.85 & -3.61 \\
\hline Vegetation & -16.80 & -4.25 & -23.92 & -6.22 & -15.97 & -4.58 & -6.94 & -2.07 & -5.53 & -1.64 \\
\hline Wetlands & -6.82 & -5.26 & -16.53 & -13.67 & -9.43 & -9.04 & -6.34 & -6.68 & -1.65 & -1.87 \\
\hline Cropland & -74.40 & -14.71 & -49.77 & -11.54 & -50.51 & -13.24 & -15.94 & -4.81 & -1.57 & -0.50 \\
\hline Built up & 115.01 & 25.51 & 101.16 & 17.88 & 78.66 & 11.79 & 39.84 & 5.34 & 11.96 & 1.52 \\
\hline Bare land & -13.47 & -5.35 & -10.18 & -4.27 & -0.61 & -0.27 & -8.29 & -3.64 & -1.36 & -0.62 \\
\hline
\end{tabular}

\subsection{Urban expansion}

KUA is the third most populated city in India which has experienced rapid urbanization from 1990 to 2020 . The built-up land was expanded from $450.86 \mathrm{~km}^{2}$ during 1990 to $745.69 \mathrm{~km}^{2}$ during 2020 (Fig. 4) and the growth rate of built-up land was $65.39 \%$ during the period 1990 to 2020 (Table 4). The population was increased by $75.29 \%$ from 1991 to 2021 . The trend of change of built-up land is directly coinciding with the change of population in KUA. During the period 2001-2021 the growth rate of population as well as built-up land remained lower than other decades. Fig. 4 showed the spatial expansion of built-up land from 1990 to 2040. The expansion of built-up land was high in south Kolkata (Sonarpur and Baruipur Municipality, Bhangar-I and Bhangar-II) and mainly expanded after 2000.

Table 4

Urban expansion along with population growth in KMA from 1990 to 2020

\begin{tabular}{|llll|}
\hline Years & Growth of built-up land (\%) & Years & Growth of population (\%) \\
\hline $1990-2000$ & 25.51 & $1991-2001$ & 55.41 \\
\hline $2000-2010$ & 17.88 & $2001-2011$ & 6.81 \\
\hline $2010-2020$ & 11.79 & $2011-2021$ & 5.60 \\
\hline $1990-2020$ & 65.39 & $1991-2021$ & 75.29 \\
\hline
\end{tabular}

\subsection{Assessment of ESV from 1990 to 2040}

The assessment of ESV has three dimensions- (1) Examining spatio-temporal variation of ESV in the present landscape scenario from 1990 - 2040; (2) Tracing out ecosystem services function and contribution of regulating, provisional, supporting and cultural ESs from 1990 - 2040; and (3) calculating LULC wise contribution of ESV in the study landscape scenario during the study period. 


\subsubsection{Spatio-temporal assessment of ESV}

Figure 5 showed the spatio-temporal distribution of ESVs within KUA for the period of fifty years. Grid wise analysis of ESV was done and it was classified into 5 groups - very low $(<453.80)$, low $(\$ 453.81-\$ 619.60)$, moderate $(\$ 619.61-\$ 851.60)$, high $(\$ 851.61-\$ 1229.60)$ and very high (>\$1229.61). Higher orders of ESV sites were mainly concentrated at the eastern part of KUA where wetlands are situated. It was observed that $16.60 \%$ of the grids were under very low ESV group during 1990 , which has been increased to $41.47 \%$ during 2020 and will be increased to $58.88 \%$ during 2040 ; whereas $2.69 \%$ of the grids belonged to very high ESV during 1990 , has been decreased to $2.54 \%$ during 2020 and will be decreased to $2.35 \%$ during 2040 (Table 5). The area of higher order ESV (\$619.61-\$1229.60) will decrease from $41.26-16.18 \%$ during 1990 - 2040. Rapid increase of ESV of lower order (<\$453.80) has link with rapid increase of builtup area in KUA.

Table 5

Levels of ESV and their spatial extent in KUA for various time periods

\begin{tabular}{|c|c|c|c|c|c|c|c|c|c|}
\hline \multirow[t]{2}{*}{ ESV Category } & \multirow[t]{2}{*}{ ESV score } & \multicolumn{2}{|l|}{1990} & \multicolumn{2}{|l|}{2020} & \multicolumn{2}{|l|}{2030} & \multicolumn{2}{|l|}{2040} \\
\hline & & $\mathrm{km}^{2}$ & $\%$ & $\mathrm{~km}^{2}$ & $\%$ & $\mathrm{~km}^{2}$ & $\%$ & $\mathrm{~km}^{2}$ & $\%$ \\
\hline Very low & $\$ 453.80$ and below & 297.31 & 16.60 & 742.90 & 41.47 & 897.39 & 50.09 & 1054.73 & 58.88 \\
\hline Low & $\$ 453.81-\$ 619.60$ & 706.71 & 39.45 & 567.92 & 31.70 & 522.07 & 29.14 & 404.68 & 22.59 \\
\hline Moderate & $\$ 619.61-\$ 851.60$ & 652.29 & 36.41 & 358.46 & 20.01 & 265.21 & 14.80 & 226.48 & 12.64 \\
\hline High & $\$ 851.61-\$ 1229.60$ & 86.96 & 4.85 & 76.69 & 4.28 & 63.20 & 3.53 & 63.44 & 3.54 \\
\hline Very high & $\$ 1229.61$ and above & 48.19 & 2.69 & 45.50 & 2.54 & 43.53 & 2.43 & 42.10 & 2.35 \\
\hline
\end{tabular}

\subsubsection{Ecosystem service functions and their contribution}

The study determined the contribution of ten ecosystem service functions in the present landscape and also analysed their change rate from 1990 - 2040 (Table 6). It was found that cultural and recreation services contributed highest ESV followed by soil formation and waste treatment in every respective year; whereas water regulation and gas regulation services contributed lowest ESV. The rate of change of contribution for all the ESVs has decreased over time except biodiversity maintenance, although the absolute value of each and every ESs showed a decreasing trend. Moreover, supporting services contributed highest ESV and provisional services contributed lowest ESV in every decadal year (Table 7). More interestingly the change rate of food production, recreation and cultural value of ESs remain high in the 50 years study period. 
Table 6

ESV function and change rate of ten ecosystem services during $1990-2040$

\begin{tabular}{|c|c|c|c|c|c|c|c|c|c|c|c|c|}
\hline \multirow{3}{*}{$\begin{array}{l}\text { Ecosystem service } \\
\text { type }\end{array}$} & \multicolumn{6}{|c|}{ ESV (USD/km²/year) } & \multicolumn{6}{|c|}{ Change rate (\%) } \\
\hline & 1990 & 2000 & 2010 & 2020 & 2030 & 2040 & 1990 & 2000 & 2010 & 2020 & 2030 & 1990 \\
\hline & & & & & & & 2000 & 2010 & 2020 & 2030 & 2040 & $\overline{2} 2040$ \\
\hline Gas regulation & 51.49 & 50.79 & 49.33 & 48.19 & 47.79 & 47.83 & -1.4 & -2.9 & -2.3 & -0.8 & 0.1 & -7.1 \\
\hline Climate regulation & 100.99 & 97.61 & 94.13 & 91.10 & 90.27 & 89.70 & -3.3 & -3.6 & -3.2 & -0.9 & -0.6 & -11.2 \\
\hline Water regulation & 34.14 & 32.40 & 31.32 & 30.03 & 29.77 & 29.81 & -5.1 & -3.3 & -4.1 & -0.9 & 0.1 & -12.7 \\
\hline Soil formation & 254.77 & 244.53 & 232.52 & 223.24 & 219.91 & 217.55 & -4.0 & -4.9 & -4.0 & -1.5 & -1.1 & -14.6 \\
\hline Waste treatment & 144.60 & 141.26 & 140.35 & 137.83 & 136.54 & 135.30 & -2.3 & -0.6 & -1.8 & -0.9 & -0.9 & -6.4 \\
\hline $\begin{array}{l}\text { Biodiversity } \\
\text { Maintenance }\end{array}$ & 132.33 & 135.20 & 135.08 & 136.07 & 135.98 & 136.22 & 2.2 & -0.1 & 0.7 & -0.1 & 0.2 & 2.9 \\
\hline Food production & 86.31 & 79.83 & 71.86 & 65.95 & 63.07 & 62.26 & -7.5 & -10.0 & -8.2 & -4.4 & -1.3 & -27.9 \\
\hline $\begin{array}{l}\text { Raw materials } \\
\text { Provision }\end{array}$ & 87.00 & 83.16 & 77.68 & 73.83 & 72.10 & 71.19 & -4.4 & -6.6 & -5.0 & -2.3 & -1.3 & -18.2 \\
\hline $\begin{array}{l}\text { Recreation and } \\
\text { cultural, and } \\
\text { aesthetics }\end{array}$ & 267.74 & 260.72 & 238.35 & 225.87 & 217.02 & 214.26 & -2.6 & -8.6 & -5.2 & -3.9 & -1.3 & -20.0 \\
\hline
\end{tabular}

Table 7

Ecosystem services types and their contribution in the study area

\begin{tabular}{|lllllll|}
\hline Ecosystem services & \multicolumn{6}{l}{ ESV (USD/ yr) } \\
\cline { 2 - 7 } & $\mathbf{1 9 9 0}$ & $\mathbf{2 0 0 0}$ & $\mathbf{2 0 1 0}$ & $\mathbf{2 0 2 0}$ & $\mathbf{2 0 3 0}$ & $\mathbf{2 0 4 0}$ \\
\hline Regulating & 1866.19 & 1808.02 & 1747.85 & 1693.22 & 1678.31 & 1673.46 \\
\hline Provisional & 1733.13 & 1629.92 & 1495.34 & 1397.80 & 1351.70 & 1334.52 \\
\hline Supporting & 5317.06 & 5209.91 & 5079.51 & 4971.33 & 4924.34 & 4890.69 \\
\hline Cultural & 2677.43 & 2607.19 & 2383.45 & 2258.70 & 2170.16 & 2142.58 \\
\hline
\end{tabular}

\subsubsection{LULC contribution to ESV}

According to our observation, the vegetation and wetlands together had contributed nearly $62.2 \%$ of the total ESV in 1990 , but will be decreased to $50.3 \%$ in the year 2040 . The contribution was $\$ 4036.71$ and $\$ 3066.93$ in 1990 but it will be decreased to $\$ 3331.79$ and \$2089.59 from 1990 to 2040, respectively, for vegetation and wetlands (Table 8). The sub-urbanization process caused to transformation of both wetlands and vegetation to built-up land and make significant impact of such degradation of ESV. The contribution of cropland, built-up and river was $19.28 \%, 12.49 \%$ and $5.14 \%$ respectively for the year 1990 . It has predicted that contribution of built up will be $25.50 \%$ in the year 2040 . In the present landscape, contribution from bare land was not significant. Table 8 showed that contribution of ESV in each and every LULC were decreased in between $1990-2040$ except built-up land, which means natural ecosystem characteristics are modified to human based ecosystem. 
Table 8

ESV provided by various LULC types from the year 1990 to 2040

\begin{tabular}{|c|c|c|c|c|c|c|c|c|c|c|c|c|}
\hline \multirow[t]{3}{*}{ LULC type } & \multicolumn{6}{|c|}{$\mathrm{ESV}\left(\mathrm{USD} / \mathrm{km}^{2}\right)$} & \multicolumn{6}{|c|}{ Change rate (\%) } \\
\hline & \multirow[t]{2}{*}{1990} & \multirow[t]{2}{*}{2000} & \multirow[t]{2}{*}{2010} & \multirow[t]{2}{*}{2020} & \multirow[t]{2}{*}{2030} & \multirow[t]{2}{*}{2040} & 1990 & 2000 & 2010 & 2020 & 2030 & 1990 \\
\hline & & & & & & & 2000 & 2010 & 2020 & 2030 & 2040 & 2040 \\
\hline River & 59.65 & 56.15 & 55.40 & 53.27 & 50.95 & 49.11 & -5.9 & -1.3 & -3.8 & -4.4 & -3.6 & -17.7 \\
\hline Vegetation & 403.67 & 386.51 & 362.48 & 345.88 & 338.73 & 333.18 & -4.3 & -6.2 & -4.6 & -2.1 & -1.6 & -17.5 \\
\hline Wetlands & 306.69 & 290.56 & 250.83 & 228.17 & 212.93 & 208.96 & -5.3 & -13.7 & -9.0 & -6.7 & -1.9 & -31.9 \\
\hline Crop land & 223.57 & 190.68 & 168.68 & 146.35 & 139.30 & 138.61 & -14.7 & -11.5 & -13.2 & -4.8 & -0.5 & -38.0 \\
\hline Built up & 144.77 & 181.70 & 214.18 & 239.43 & 252.23 & 256.07 & 25.5 & 17.9 & 11.8 & 5.3 & 1.5 & 76.9 \\
\hline Bare land & 21.03 & 19.91 & 19.06 & 19.01 & 18.31 & 18.20 & -5.3 & -4.3 & -0.3 & -3.6 & -0.6 & -13.5 \\
\hline Total & 1159.38 & 1125.50 & 1070.61 & 1032.10 & 1012.45 & 1004.13 & -2.9 & -4.9 & -3.6 & -1.9 & -0.8 & -13.4 \\
\hline
\end{tabular}

\subsection{Change rate of ESV}

We have prepared ESV change rate (\%) map during the period of 1990 - 2000, $2010-2010,2010-2020,2020-2030$ and $2030-$ 2040 (Fig. 6). It has noticed that change rate of ESV was high in the sub urban areas in between $1990-2000$ and it was more or less stable up to 2010. But after that period high ESV change rate was significantly noticed in the urban core areas (during 2010 - 2020) and will continuously spreading towards its peripheral region in between $2020-2040$. LULC change, especially transformation natural ecosystem to urban ecosystem is the main reason for such changes.

\section{Discussions}

\subsection{Effect of natural and anthropogenic activity on LULC change}

Precipitation and temperature are the very important factors which influence urban ecology. In Kolkata urban agglomeration the precipitation has been increasing and temperature has been decreasing over the past thirty years (Fig. 7). Therefore, traditionally this area is conducive for crop and tree growth. Enough rainfall is also having potential to facilitate for spreading and maintaining of water bodies. With these positive environmental factors there is one aspect in rainfall which mainly determines its storage and its influence on vegetation, which is the rainfall distribution. The rainfall distribution in KUA region is highly skewed. More than 80 per cent of annual rainfall occurs during four monsoon months (June-September) (Ramchandra and Aithal, 2014). During this time the runoff and stream flow increases tremendously, keeping very less chance for water infiltration and storage in the water bodies. Flat topography also hinders in storing the excess water which is flowing over land. Water scarcity during winter and summer season reduces the green patches within KUA. Apart from the climatic factors, anthropogenic factors play very important role in changing the LULC in KUA. KUA is one of the biggest cities in south-east Asia, where business development has been increased tremendously. The built-up land was increased many folds within a span of thirty years and the growth rate of built-up land was $65.39 \%$ during the period 1990 to 2020 . During the same period the population was increased by over $75 \%$.

The anthropogenic activities which have governed the ecosystem services are common in various megacities in south-east Asia. Kumar (2009) has studied the anthropogenic pressure on urban green spaces and ecosystems of Delhi state of India. That study mainly focussed on biodiversity change due to change of urbanization. The shrinkage of wetlands in Kolkata was investigated by Bhattacharya et al. (2012) and concluded about the importance of construction of wastewater treatment plants. In Bangalore city of India, Jaganmohan et al. (2012) emphasized about the importance of domestic gardens and apartment gardens to conserve biodiversity in urban ecosystem. The conservation of biodiversity has positive impact on ecosystem services. Therefore, integrated ecosystem services valuation and the greater effect of human on ESV cannot be ignored in fragile urban areas like Kathmandu in Nepal (Peh et al., 2016). The impact of anthropogenic activity on the changing pattern of ecosystem services of urban cities of Myanmar has been studied by Wang et al. (2018). Recently Zinia and McShane (2021) assessed and mapped the ecosystem services of Dhaka city of Bangladesh where they considered that climate and anthropogenic activities play the most dominant role for changing the ESVs. The 
expansion of urban area causes to degradation of natural ecosystem and changes of ecosystem services. This phenomenon linked with the process of ecosystem degradation in KUA.

\subsection{LULC change versus ESV change}

The changes in LULC scenario are the primary reason for the loss of ESV or the shifts of the type of ESs from one to another (Zhang and Gao, 2020; Das and Das, 2019b; Lang and Song, 2019). In the KUA, the patterns of LULC change have been very dynamic during the year 1990 to 2020. In the first phase of 1990-2000, the massive growth of built-up area has been noticed, which has mainly reduced agricultural land. In the second phase of 2000 - 2010, high growth of built-up area has been continued but with quite low pace as compare to the first phase. The loss of wetlands has very high in this phase, which mainly transformed to the built-up land. Sahana et al. (2018) studied on urban spatial pattern and landscape change scenario. They noticed that urban secondary and primary core area were rapidly increased. The expansion of sub-urban fringe and scatter settlement areas also significantly noticed. Our analysis experienced that spatial process of urban expansion caused to shift of ESV in both urban core and sub-urban fringe areas. Many stakeholders are also affected both positively and negatively by the change of ESV. Natural habitat and wellbeing of other living organisms hampered due such ESV change.

Das and Das (2019b) classified the dimensions of urbanization into four categories - population urbanization, economic urbanization, lifestyle urbanization and landscape urbanization. Growth of population is the main indicator under population urbanization, which is the main feature of the development of a modern city and can changes natural resource consumption. Economic urbanization means a group of economic activities accommodated within cities and the distribution of this growth across cities of different sizes. Rich, material wellbeing, enrichment of civilization, education, improvement in living standards, etc. are the aspects of lifestyle urbanization. This type of urbanization cannot be spatially describable. But landscape urbanization means LULC changes and expansion of built-up land, which has links to population growth and leads to loss of natural landscape. Because of this reason, the present study considered landscape urbanization and its impacts on ecosystem services.

\subsection{Global comparison of ESV}

Costanza et al. (2014) reported the global terrestrial ESV during the year of 1997-2011 based on 1997-unit values. The global terrestrial ESV decreased by $28.82 \%$ due to LULC change. Our observation also reveals that total ESV in KUA was decreased by $21.04 \%$ during the phase 1990-2020 and will be decrease by $27.09 \%$ during the phase $1990-2040$. Thus, the rate change in ESV in KUA was very close to global rate. The change rate of total ESV has been noted as very dynamic as it increased during first to second decadal phase, while it has slowed down during later decade. Globally, the shrinking of high ESVs areas like forests and wetlands was the main reasons for the drastic decrease in ESVs. During the phase 1997-2011, global vegetation and wetlands areas declined by $0.87 \%$ and $3.59 \%$ per year, respectively, while vegetation and wetlands areas in KUA decreased by $0.48 \%$ and $0.85 \%$ per year during the observed period of $1990-$ 2020.

\subsection{Policy implications}

The wetlands and vegetation areas are the two main sensitive areas of natural capitals. In KUA we are losing $0.86 \%$ wetland area per year (during 1990 - 2020), which was slightly greater of global rate (Das et al., 2021) and two times greater than vegetation area shrinkage rate ( $0.45 \%$ per year). Therefore, priority in landscape policy formulation and planning should be emphasized to protect wetlands areas. Strict environmental influence analyses should be implemented, by focusing to conserve the agricultural areas located in the periphery of KUA. To improve the overall ESVs of KUA, targeted approach under various scenarios will be the most suitable. Although scenario analysis may not be the true representation of the future but it can act as supporting instrument in policy development and decision making (Guerra et al., 2017). A scenario analysis to improve the ESVs of KUA has been shown in Fig. 8. First, the probable pathways were identified and a target was set with a fixed time-frame basis. To achieve the target, the design was made where the landscape planning and decision-making processes were considered. Different policies were assessed and the most practically implementable policy was chosen. After implementation of the policy, mid-term review needs to be done and based on the result, certain changes in the implementation, if needed, should be done. By this targeted scenario approach the ESVs of KUA should be improved and its effect will be felt by the society. Among the land uses, wetlands are most sensitive to changes in ESVs and most of the wetlands are situated along the eastern border of KUA. Protecting these wetlands and river banks from urban encroachment is necessary to increase the ESVs in future.

Nowadays, the management of ESs are also an important concept for sustainable landscape planning and decision-making process, because it can address the trade-off analysis and synergies between environment and socio-economic goals (Fig. 9). Trade-offs deals

Page $10 / 21$ 
with the negative changes of ecosystem service value due to LULC change and synergies govern the improvement of ESs which should be appropriate in that region. The concept allows for better understanding to the policy makers. Rapid urbanization in KUA has tradeoffs in supply of ESVs which need to be optimized by setting certain targets at the specified time periods. Different policy sectors like environmental policy (climate and water policy), agricultural and rural development policy, regional development policy and strategies (biodiversity, forest strategy) have come out to enhance the ecosystem services. The regional development policy state that the potentiality of ecosystem services can be applied for landscape planning at regional and local level, which aims to enhancing, restoring or creating landscape and related services. With the consideration of the landscape scenario of Kolkata urban agglomeration, it is very essential to set landscape functions and capacity to fulfil not only for human demand but also other organisms.

The conversion of public as well as private open spaces to urban green spaces in KUA is a useful measure for protecting urban environmental quality. Urban green spaces produced ecosystem services can supply regulating services (biodiversity and climate regulation) and creates cultural services. It should be prioritizing on public areas like parks, sports fields, river banks and other riparian areas, walkways and trails, communal shared gardens, street trees and bushes, nature conservation areas, and less conventional spaces in KUA. The ecosystem services provided by green space can improve the environmental condition, pollution, and congestion of the large urban areas like Kolkata urban agglomeration.

\subsection{Limitations of the study}

The main limitation of the present study would be associated with the LUCC map that obtained by support vector machine classification technique and the predicted LULC map obtained by CA-Markov chain model. Although, the CA-Markov model is very effective in simulating LULC pattern but it cannot precisely address human disturbances and spatial change of landscape scenario. Therefore, certain errors and uncertainties exist in the results of the simulation. Some of these errors are mainly described by the limitations of the image classification techniques and the internal doubtfulness in the model that result from the transition rules.

The estimation and prediction of ESVs based on the global coefficient values given by Costenza et al. (1997) was popular to decision makers and planners at broad geographical scales, but it require some field validation. Everard et al. (2019) calculated ESVs using field based rapid assessment of ecosystem services method of selected wetlands of Kolkata and Indian Gangetic delta after selecting some of the wetland sites. But site selection of each and every LULC types is very difficult and complicated task and needs some high-quality instrument. Therefore, the coefficient value of Costenza et al. (1997) is used for scenario analysis and decision making when estimating and predicting ecosystem services at broad geographical scales because of quick assessment and the low cost for collecting field data.

\section{Conclusion}

In the current study, rapid urbanization in Kolkata urban agglomeration causes in changes of ecosystem services under present and projected land use land cover scenario from 1990 to 2040 has been analysed. The study determined the following outcomes as given below:

1. The total ESV has been decreased from $\$ 11593.8$ to $\$ 10321.0$ during the period of $1990-2020$ with annual rate $-0.37 \%$ and it will decrease from $\$ 10321.0$ to $\$ 10041.3$ during the period of $2020-2040$ with annual rate of $-0.15 \%$.

2. The built-up land was increased from $450.86 \mathrm{~km}^{2}$ to $754.69 \mathrm{~km}^{2}$ with annual rate of $2.18 \%$ during the period from 1990 to 2020 . It is also estimated that built-up land will be increased by annual rate $0.35 \%$ in between 2020 to 2040 .

3. Globally, wetlands used to provide maximum ecosystem service value among the observed LULC types. Our analysis also illustrate that wetlands provided $26.45 \%$ of the total ESV in the year 1990 and decreased to $22.11 \%$ in 2020 and will be settled to $20.81 \%$ by 2040. Thus, shrinking of wetland area and wetland degradation play pivotal role for the decrease of ESV.

4. The grid wise spatial-temporal distribution of ESV was classified into five groups: very low (<\$453.80), low (\$453.81 -\$619.60), moderate (\$619.61 $-\$ 851.60)$, high (\$851.61 $-\$ 1229.60)$ and very high (> $\$ 1229.61)$. We studied that $16.60 \%$ of grids are residing in very low ESV in 1990 and will be increase to $58.88 \%$ in 2040; and $2.69 \%$ of grids belongs to very high ESV and will be decrease in $2.35 \%$ in 2040.

5. Targeted scenario analysis approach can improve the ESVs in KUA which conceptualized the sustainable landscape planning and decision-making process. This approach is very important because it can address the trade-off analysis and synergies between environment and socio-economic goals. 
The information of this study can contribute for decision making process in sustainable management of natural resources and also provide some useful guideline for the improvement of environmental quality in the study landscape.

\section{Declarations}

Ethics approval and consent to participate: "Not applicable"

\section{Consent for publication: "Not applicable"}

Availability of data and materials: "The datasets used and/or analysed during the current study are available from the corresponding author on reasonable request"

Competing interests: "The authors declare that they have no competing interests"

Conflict of Interest: "No potential conflict of interest was reported by the authors"

Funding: "This research was supported by the Department of Geography, Raja N. L. Khan Women's College (Autonomous), affiliated to Vidyasagar University, Midnapore, West Bengal, India"

\section{References}

1. Alcamo, J., Ash, N.J., Butler, C.D., Callicot, J.B., Capistrano, D., Carpenter, S.R., 2003. Ecosystems and Human Well Being: A Framework for Assessment. Island Press: Washington, DC, USA.

2. Aronson, M.F.J., La Sorte, F.A., Nilon, C.H., Katti, M., Goddard, M.A., Lepczyk, C.A., Warren, P.S., Williams, N.S.G., Cilliers, S., Clarkson, B., Dobbs, C., Dolan, R., Hedblom, M., Klotz, S., Kooijmans, J.L., Kuhn, I., MacGregor-Fors, I., McDonnell, M., Mortberg, U., Pysek, P., Siebert, S., Sushinsky, J., Werner, P., Winter, M., 2014. A global analysis of the impacts of urbanization on bird and plant diversity reveals key anthropogenic drivers. Proc. R. Soc. B Biol. Sci. 281, 20133330. https://doi.org/ 10.1098/rspb.2013.3330.

3. Bhattacharya S, Ganguli A, Bose S, Mukhopadhyay A (2012). Biodiversity, traditional practices and sustainability issues of East Kolkata wetlands: a significance Ramsar site of West Bengal, (India). Res Rev Biosci 6(11):340-347.

4. Bohnet, I. C., \& Pert, P. L., 2010. Patterns, drivers and impacts of urban growth- a study from Cairns, Queensland, Australia from 1952 to 2031. Landscape and UrbanPlanning. 97(4): 239-248.

5. Bolund, P., Hunhammar, S., 1999. Ecosystem services in urban areas. Ecol. Econ. 29: 293-301. https://doi.org/10.1016/S09218009(99)00013-0.

6. Chapin, F.S., Matson, P.A., Vitousek, P.M., 2012. Principles of Terrestrial Ecosystem Ecology. Springer, New York.

7. Chen, B., Chen, G.Q., 2007. Modified ecological footprint accounting and analysis based onembodied exergy - a case study of the Chinese society 1981-2001. Ecol. Econ. 61: 355-376.

8. Costanza, R., d'Arge, R., Belt, V.N.M., 1997. The value of the World's ecosystem services and natural capital. Nature, $387: 253-260$.

9. Costanza, R., Daly, H., 1992. Natural capital and sustainable development. Conservation Biology. 6: 37 - 46.

10. Costanza, R., de Groot, R., Sutton, P., Ploeg, V.S., Anderson, J.S., Kubiszewski, I., Farber, S., Turner, K.R., 2014. Changes in the global value of ecosystem services. Global Environment change. 26: $152-158$.

11. Daily, G.C., 1997. Nature's services: societal dependence on natural ecosystems. Ecology. https://doi.org/10.1023/a:1023307309124.

12. Daniel, T.C., Muhar, A., Arnberger, A., Aznar, O., Boyd, J.W., Chan, K.M., Grêt-Regamey, A., 2012. Contribution of cultural services to the ecosystem services agenda. Proc. Natl. Acad. Sci. USA. 109: 8812-8819.

13. Danz, N.P., Niemi, G.J., Regal, R.R., Hollenhorst, T., Johnson, L.B., Hanowski, J.M., Axler, R.P., Ciborowski, J.J., Hrabik, T., BradyV.J., 2007. Integrated measures of anthropogenic tress in the US Great Lakes basin. J. Environ. Manage. 39: 631 - 647.

14. Das, I., Das, A., 2019. Exploring the dynamics of urban sprawl using geo-spatial indices: a study of English Bazar Urban Agglomeration, West Bengal. Appl. Geomat. 11: 259-276.

15. Das, M., Das, A., 2019b. Dynamics of Urbanization and its impact on Urban Ecosystem Services (UESs): A study of a medium size town of West Bengal, Eastern India. Journal of Urban Management. 8: 420 - 434. 
16. Das, S., Adhikary, P.P., Shit, P.K. and Bera, B. 2021. Urban wetland fragmentation and ecosystem service assessment using integrated machine learning algorithm and spatial landscape analysis. Geocarto International, 1-19. https://doi.org/10.1080/10106049.2021.1985174.

17. de Groot, R., Brander, L., van der Ploeg, S., Costanza, R., Bernard, F., Braat, L., et al., 2012.Global estimates of the value of ecosystems and their services in monetary units. Ecosyst. Serv. 1: 50-61.

18. Derkzen, L.M., Teeffelen, A.J.A., Verburg, H.P., 2015. Quantifying urban ecosystem services based on high-resolution data of urban green space: an assessment for Rotterdam, the Netherlands. Journal of Applied Ecology. 52 (4): 1020 - 1032.

19. Ehrlich, P.R., Ehrlich, A.H., 1981. Extinction: the causes and consequences of the disappearance of species. Random House, New York.

20. Elkhrachy, I., 2015. Flash flood hazardmapping using satellite image and GIS tools: a case study of Najran city, Kingdom of Saudi Arabia KSA. Egypt. J. Remote Sens. Space. Sci. 18: 261-278.

21. Everard, M., Kangabam, R., Tiwari, K.M., Mclnnes, R., Kumar, R., Talkdar, H.G., Dixon, H., Joshi, P., Allan, R., Joshi, D., Das, L., 2019. Ecosystem service assessment of selected wetlands of Kolkata and the Indian Gangetic Delta: multi-beneficial systems under differentiated management stress. Wetlands Ecol Manage. 27: 405 - 426.

22. Gao, J., Li, F., Gao, H., Zhou, C., Zhang, X., 2017. The impact of land-use changes on water-related ecosystem services: a study of the Guishui River Basin, Beijing, China. J. Cleaner Prod. 163: S148-S155.

23. Ghosh, A., Das, A., 2019. Urban expansion included vulnerability assessment of East Kolkata Wetland using Fuzzy MCDM method. Remote Sens Appl Soc Environ. 13: 191 - 203.

24. Guan D, Li H, Inohae T, Su W, Nagaie T, Hokao K (2011) Modeling urban land use change by the integration of cellular automaton and Markov model. Ecol Model. 222(20-22):3761-3772.

25. Guerra, C., Alkemade, R. and Maes, J. (2017). When to map? In: Burkhard, B. And Maes, J. (eds). Mapping ecosystem services. Pensoft Publishers, Sofia, 374 pp.

26. Gupta, A., 2002. Geoindicators for tropical urbanization. Environ. Geol. 42: 736-742.https://doi.org/10.1007/s00254-002-0551-x.

27. He, C., Zhang, D., Huang, Q., \& Zhao, Y., 2016. Assessing the potential impacts of urban expansion on regional carbon storage by linking the LUSD-urban and InVEST models. Environmental Modelling \&amp. Software. 75: 44-58.

28. JaganmohanM, Vailshery LS, Gopal D, Nagendra H (2012) Plant diversity and distribution in urban domestic gardens and apartments in Bangalore, India. Urban Ecosyst 15(4):911-925. https://doi.org/10.1007/s11252-012-0244-5.

29. Kang, H., Seely, B.,Wang, G., Innes, J., Zheng, D., Chen, P.,Wang, T., Li, Q., 2016. Evaluating management trade-offs between economic fibre production and other ecosystem services in a Chinese-fir dominated forest plantation in Fujian Province. Sci. Total Environ. 557-558: 80-90.

30. Keshtkar, H., Voigt, W., Alizadeh, E., 2017. Land-cover classification and analysis of change using machine-learning classifiers and multi-temporal remote sensing imagery. Arab. J. Geosci. 10: 1-15.

31. Kumar P (2009) Assessment of economic drivers of land use change in urban ecosystems of Delhi, India. Ambio 38(1):35-39.

32. Lang, Y., Song, W., 2019. Quantifying and mapping the responses of selected ecosystem services to projected land use changes. Ecol. Ind. 102: 186-198.

33. Li, Y.; Li, Y.; Zhou, Y.; Shi, Y.; Zhu, X., 2012. Investigation of a coupling model of coordination between urbanization and the environment. J. Environ. Manag. 98: 127-133.

34. Liu, Y., Hou, X., Li, X., Song, B., Wang, C., 2020. Assessing and predicting changes in ecosystem service values based on land use/cover change in the Bohai Rim coastal zone. Ecological Indicators. 111: 1 - 12.

35. Lou, G., Amuti, T., Zhu, L., Mambetov, T.B., Maisupova, B., Zhang, C., 2014. Dynamics of landscape patterns in an inland river delta of Central Asia based on a cellular automata-Markov model. Reg Environ Change. DOI 10.1007/s10113-014-0638-4.

36. Maes, J., Teller, A., Erhard, M., Liquete, C., Braat, L., Berry, P., Egoh, B., Puydarrieux, P., Fiorina, C., Santos, F., 2013. Mapping and Assessment of Ecosystems and their Services. Anal. Framew. Ecosyst. Assess. Action. 5: 1-58.

37. Manoli, G., Fatichi, S., Schl“apfer, M., Yu, K., Crowther, T.W., Meili, N., Burlando, P., Katul, G.G., Bou-Zeid, E., 2019. Magnitude of urban heat islands largely explained by climate and population. Nature. 573: 55-60. https://doi.org/10.1038/s41586-019- 1512-9.

38. Millenium Ecosystem Assessment, 2003. Ecosystems and human well-being: A framework for assessment, Ecosystems and human well-being.

39. Millennium Ecosystem Assessment, 2005. Ecosystems and Human Well-being: Synthesis. Island Press, Washington DC. 
40. Mukherjee, M., 2012. Urban growth and spatial transformation of Kolkata metropolis: a continuation of colonial legacy. ARPN Journal of Science and Technology. 2: 365-380.

41. Odgaard, M.V., Turner, K.G., Bocher, P.K., Svenning, J.-C., Dalgaard, T., 2017. A multicriteria, ecosystem-service value method used to assess catchment suitability for potential wetland reconstruction in Denmark. Ecol. Ind. 77: 151-165.

42. Peh KSH, Thapa I, BasnyatM, Balmford A, Bhattarai GP, Bradbury RB, Brown C, Butchart SHM, Dhakal M, Gurung H, Hughes FMR, Mulligan M, Pandeya B, Stattersfield AJ, Thomas DHL, Walpole M, Merriman JC (2016) Synergies between biodiversity conservation and ecosystem service provision: lessons on integrated ecosystem service valuation from a Himalayan protected area, Nepal. EcosystServ 22:359-369. https://doi.org/10.1016/j.ecoser.2016.05.003.

43. Perrings, C., Folke, C., Maler, K,C., 1992. The ecology and economics of biodiversity loss: the research agenda. Ambio. 21: 201 211.

44. Ramchandra, V.T., Aithal, H.B., S., 2014. Urban structure in Kolkata: metrics and modelling through geo-informatics. ApplGeomat. 6: $229-244$.

45. Richard, R.D., Law, A., Tan, Y.A.C., Shaikh, S., Carrasco, R.L., Jaung, W., Oh, R., 2020. Rapid urbanisation in Singapore causes a shift from local provisioning and regulating to cultural ecosystem services use. Ecosystem Services. 46:1 - 9 .

46. Robards, M.D., Schoon, M.L., Meek, C.L., 2011. The importance of social drivers in the resilient provision of ecosystem services. Global Envirn. Change. 21: 522 - 529.

47. Roy, P.S., Roy, A., Joshi, P.K., Kale, M.P., Srivastava, V.K., Srivastava, S.K., et al., 2015. Development of decadal (1985-1995-2005) land use and land cover database for India. Rem. Sens. 7 (3), 2401-2430. https://doi.org/10.3390/rs70302401.

48. Rwanga, S.S., Ndambuki, J.M., 2017. Accuracy assessment of land use/land cover classification using remote sensing and gis. Int. J. Geosci. 8 (4): 611-622.

49. Sahana, M., Hong, H., Sajjad, H., 2018. Analysing urban spatial patterns and trend of urban growth using urban sprawl matrix: A study on Kolkata urban agglomeration, India. Science of the Total Environment. 628 - 629, $1557-1566$.

50. Sang, L., Zhang, C., Yang, J., Zhu, D., Yun,W., 2011. Simulation of land use spatial pattern of towns and villages based on CAMarkov model. Math. Comput. Model. 54 (3-4): 938-943.

51. Shafizadeh, M.H., Helbich, M., 2013. Spatiotemporal urbanization processes in the megacity of Mumbai, India: a Markov chains cellular automata urban growth model. ApplGeogr. 40:140-149.

52. Shao, X., Jing, C., Qi, J., Jiang, J., Liu, Q., Cai, X., 2017. Impacts of land use and planning on island ecosystem service values: A case study of Dinghai District on Zhoushan Archipelago, China. Ecol. Process. 6.

53. Song, W., Deng, X., 2015. Land-use/land-cover change and ecosystem service provision in China. Science of the total environment. 576: $705-719$.

54. Song, X.P., 2018. Global Estimates of ecosystem service value and change: taking into account uncertainties in satellite-based land cover data. Ecol. Econ. 143: 227-235.

55. Su, S.L., Li, D.L., Hu, Y.N., Xiao, R., Zhang, Y., 2014. Spatially non-stationary response of ecosystem service value changes to urbanization in Shanghai, China. Ecol. Indic. 45: 332-339.

56. Vapnik, V.N., 1998. Statistical Learning Theory. Wiley-Interscience. New York, NY, USA.

57. Wang C, Myint SW, Fan P, Stuhlmacher M, Yang J (2018) The impact of urban expansion on the regional environment in Myanmar: a case study of two capital cities. LandscEcol 33(5):765-782. https://doi.org/10.1007/s10980-018-0632-1.

58. Wang, J., Zhou, W., Pickett, S.T.A., Yu, W., 2019. A multiscale analysis of urbanization effect on ecosystem services supply in an urban mega region. Sci. Total Environ. 662: $824-833$.

59. Wang,W., Zhang, X., Wu, Y., Zhou, L., Skitmore, M., 2017. Development priority zoning in China and its impact on urban growth management strategy. Cities. 62: 1-9.

60. Wijaya, A., Marpu, P.R., Gloaguen, R., 2008. Geostatistics texture classification of tropical rainforest in Indonesia. In: Stein, S., Shi, W., Bijker, W. (Eds.), Quality aspects in spatial data mining. CRC, Boca Raton, pp. 199-210.

61. Wilson, W., \&Mattews, H.W., 1970. Man's impact on the global environment: report of the study of critical environmental problems (SCEP). Cambridge, MA: MIT Press.

62. Zhang, J., Gao, Y., 2020. Quantifying landscape pattern and ecosystem service value changes: A case study at the county level in the Chinese Loess Plateau. Global Ecology and Conservation. 23: 1 - 14. 
63. Zhange, Z., Gao, J., 2016. Linking landscape structures and ecosystem service value using multivariate regression analysis: a case study of the Chaohu Lake Basin, China. Environ Earth Sci. 75 (3): 2 - 16. DOI 10.1007/s12665-015-4862-0.

64. Zinia, N.J., McShane, P., 2021. Urban ecosystems and ecosystem services in megacity Dhaka: mapping and inventory analysis. Urban Ecosyst. DOI 10.1007/s11252-020-01076-1.

\section{Figures}

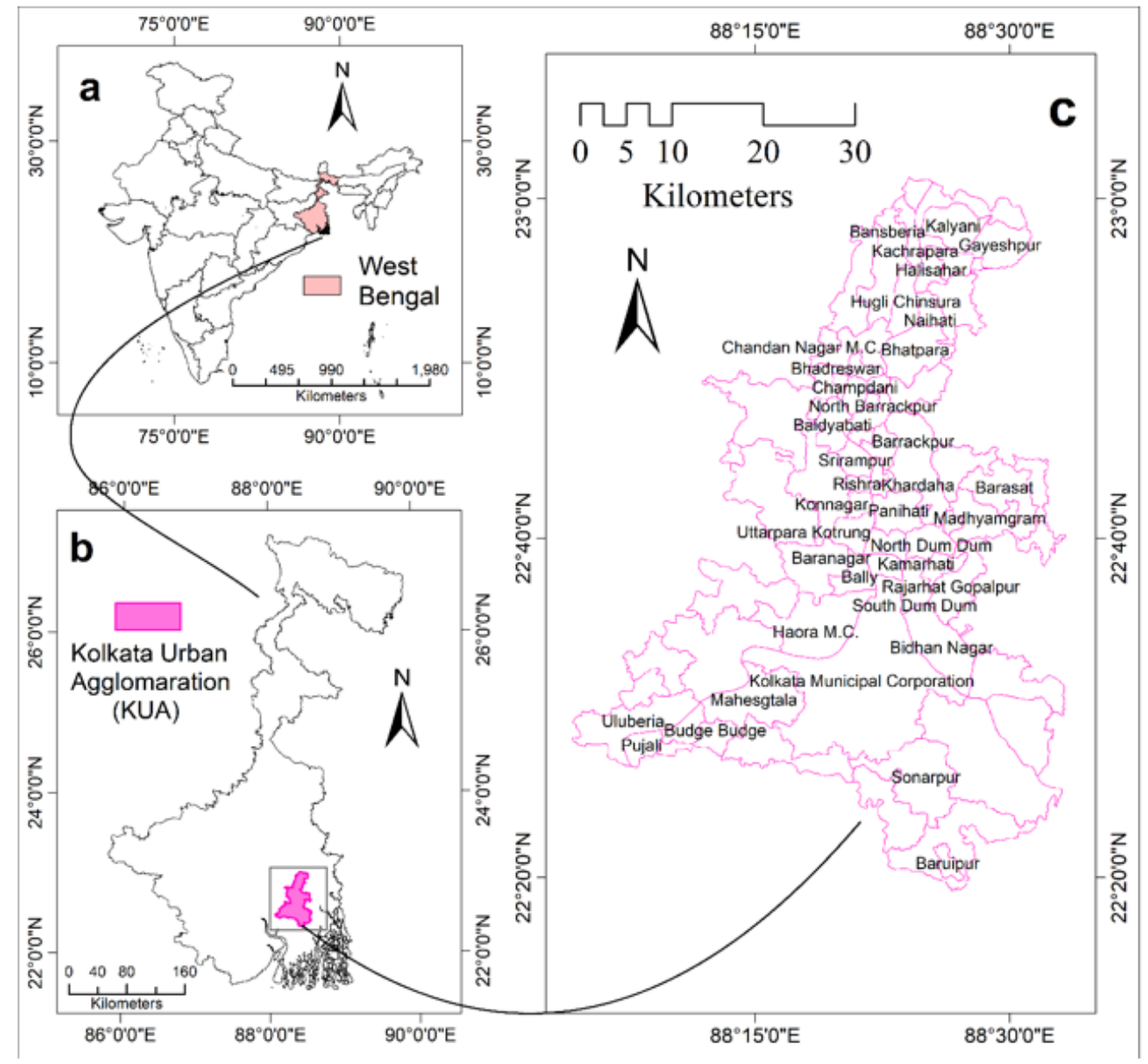

\section{Figure 1}

Location of Kolkata Urban Agglomeration (KUA), India 


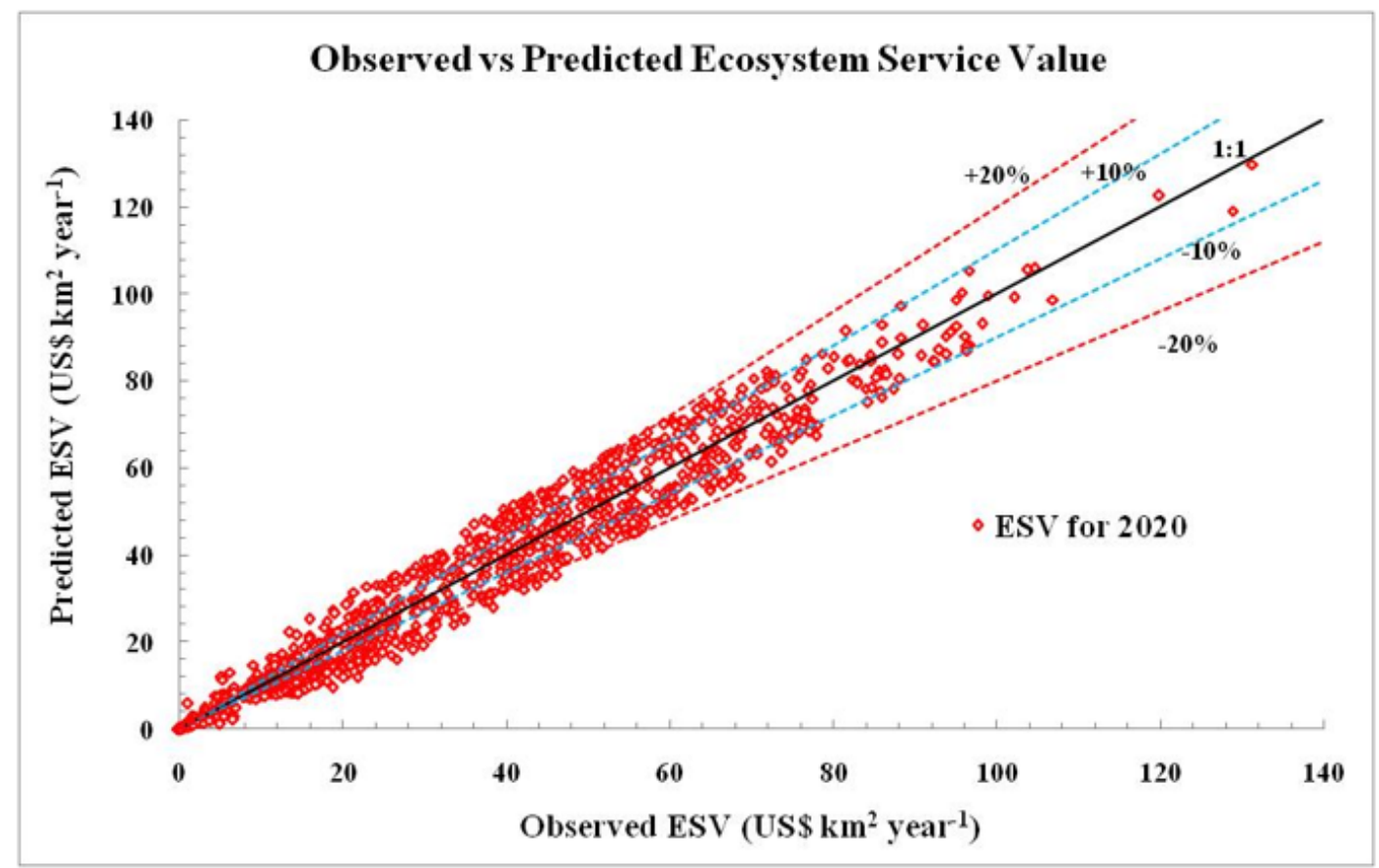

Figure 2

Observed vs. Predicted ESVs in KUA for the year 2020

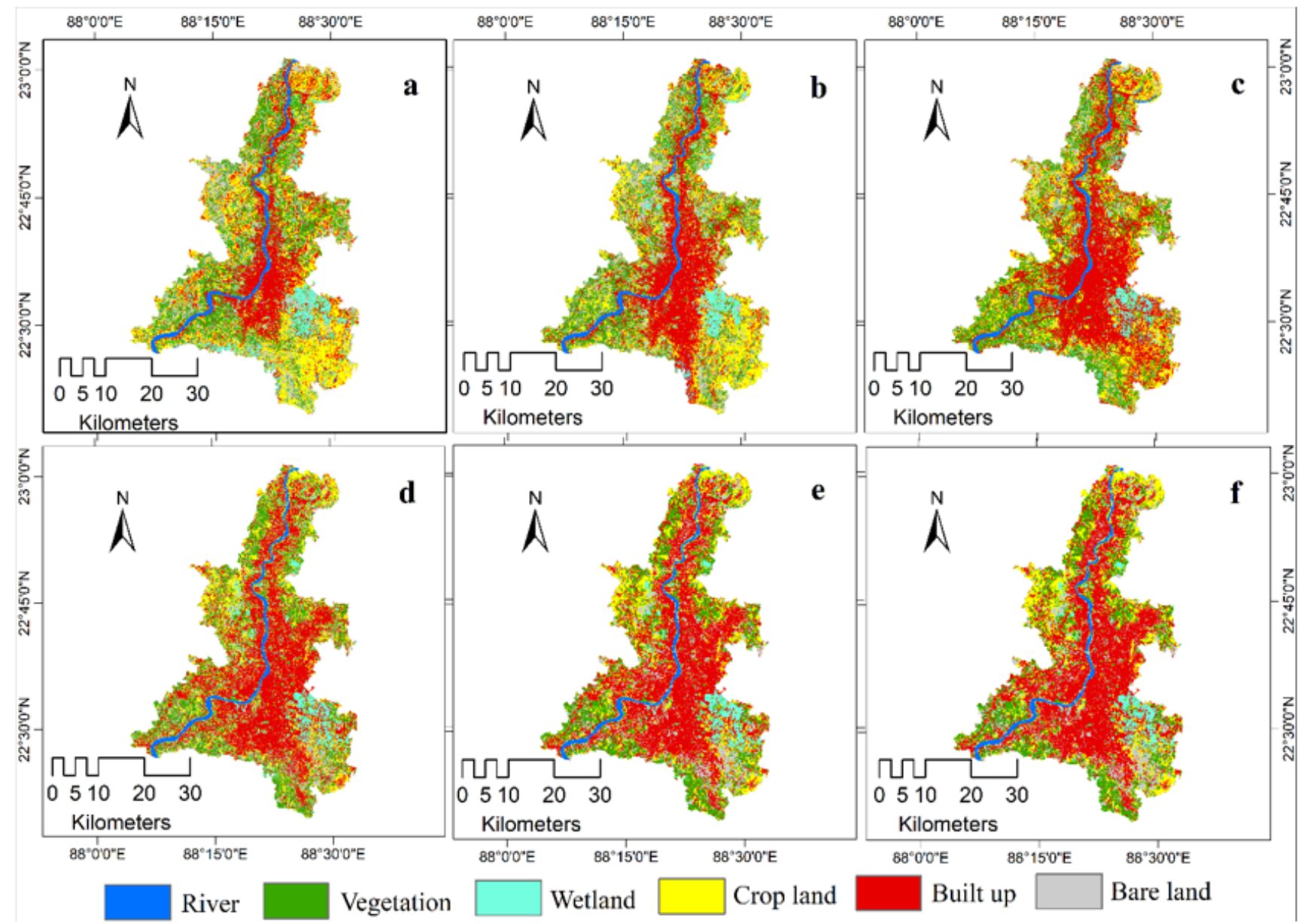

Figure 3 
LULC type map of KUA for the years (a) 1990, (b) 2000, (c) 2010, (d) 2020, (e) 2030 and (f) 2040

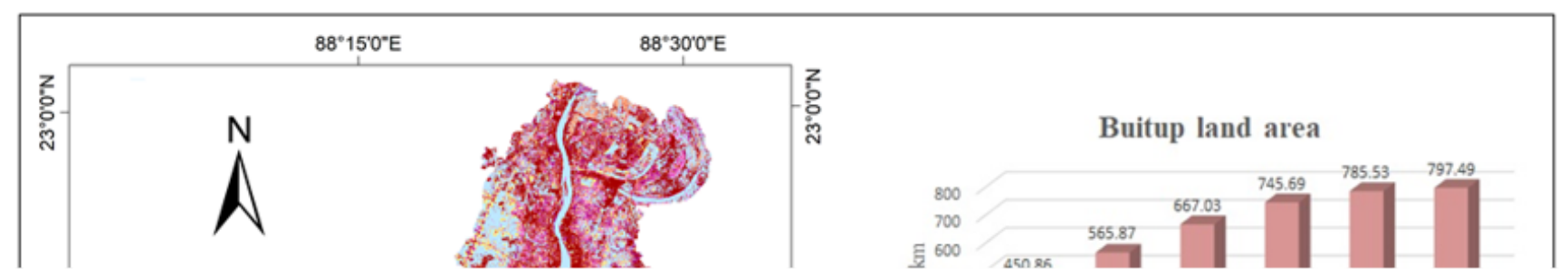

Figure 4

Spatial extent of urban expansion in KUA from 1990 to 2040 


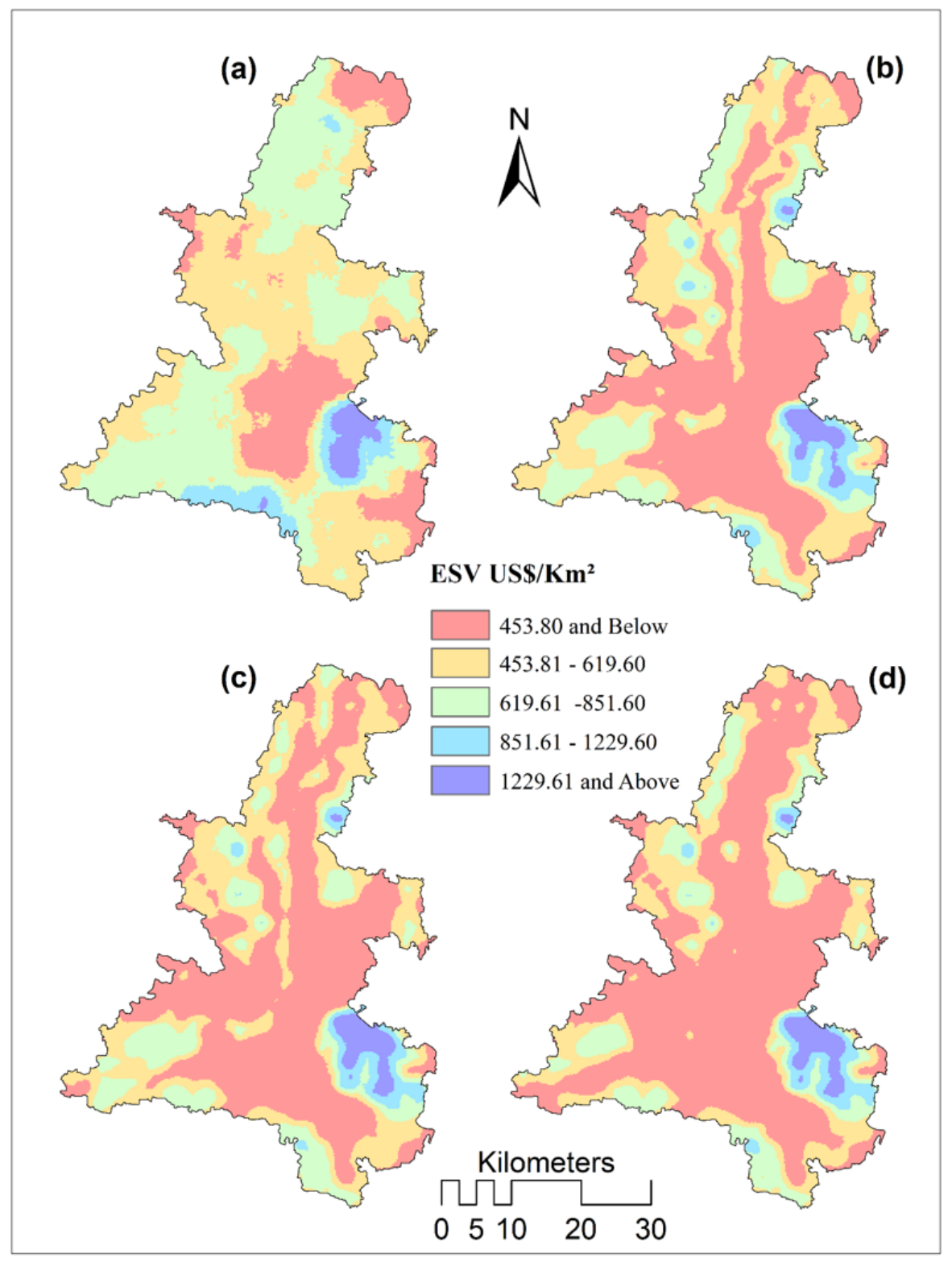

Figure 5

Spatial distribution of ranges ESV within KUA during various time periods (a) 1990, (b) 2020, (c) 2030, and (d) 2040 


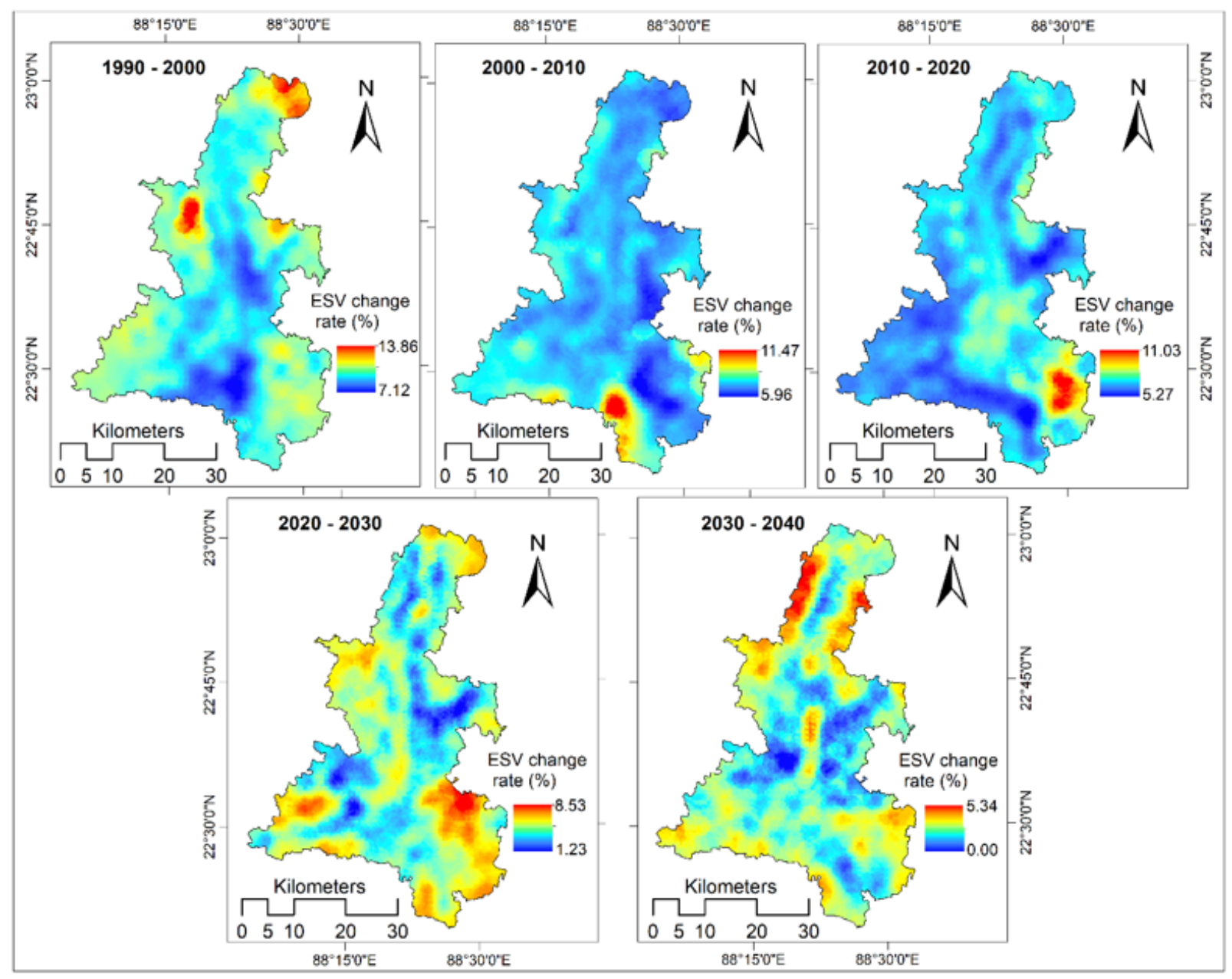

Figure 6

Spatial distribution of ESV changes rate in KUA from 1990 - 2040 


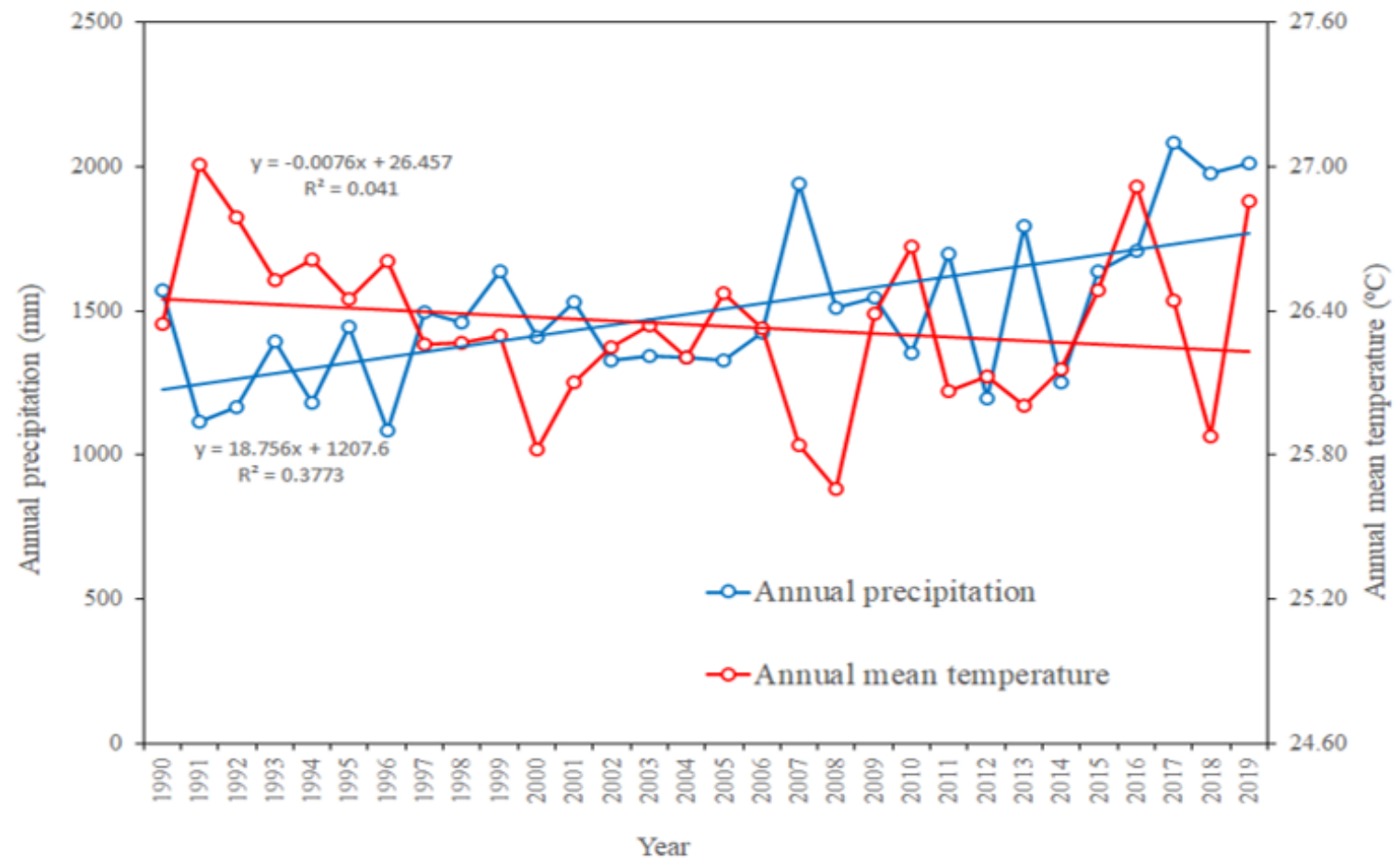

Figure 7

Changes in the climatic factors in KUA over the last 30 years
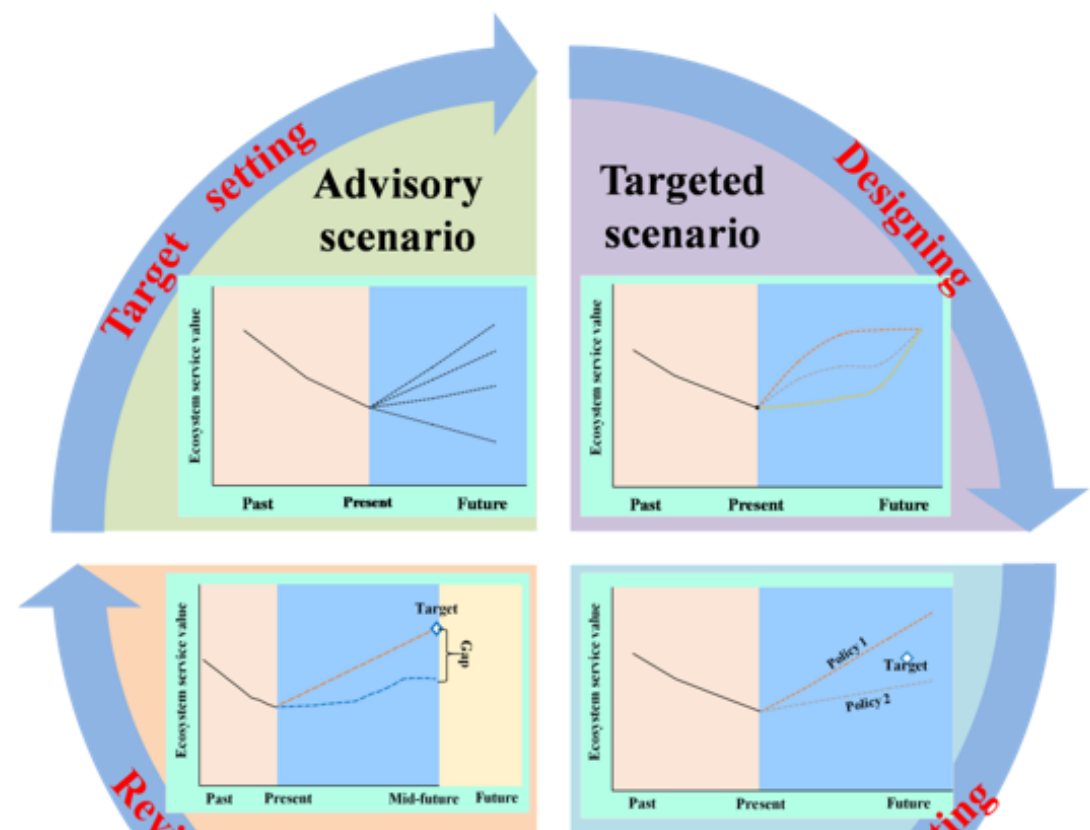

Evaluation scenario

\section{Screening} scenario

Figure 8 
Different types of target-oriented scenarios and their applicability for policy making and implementation

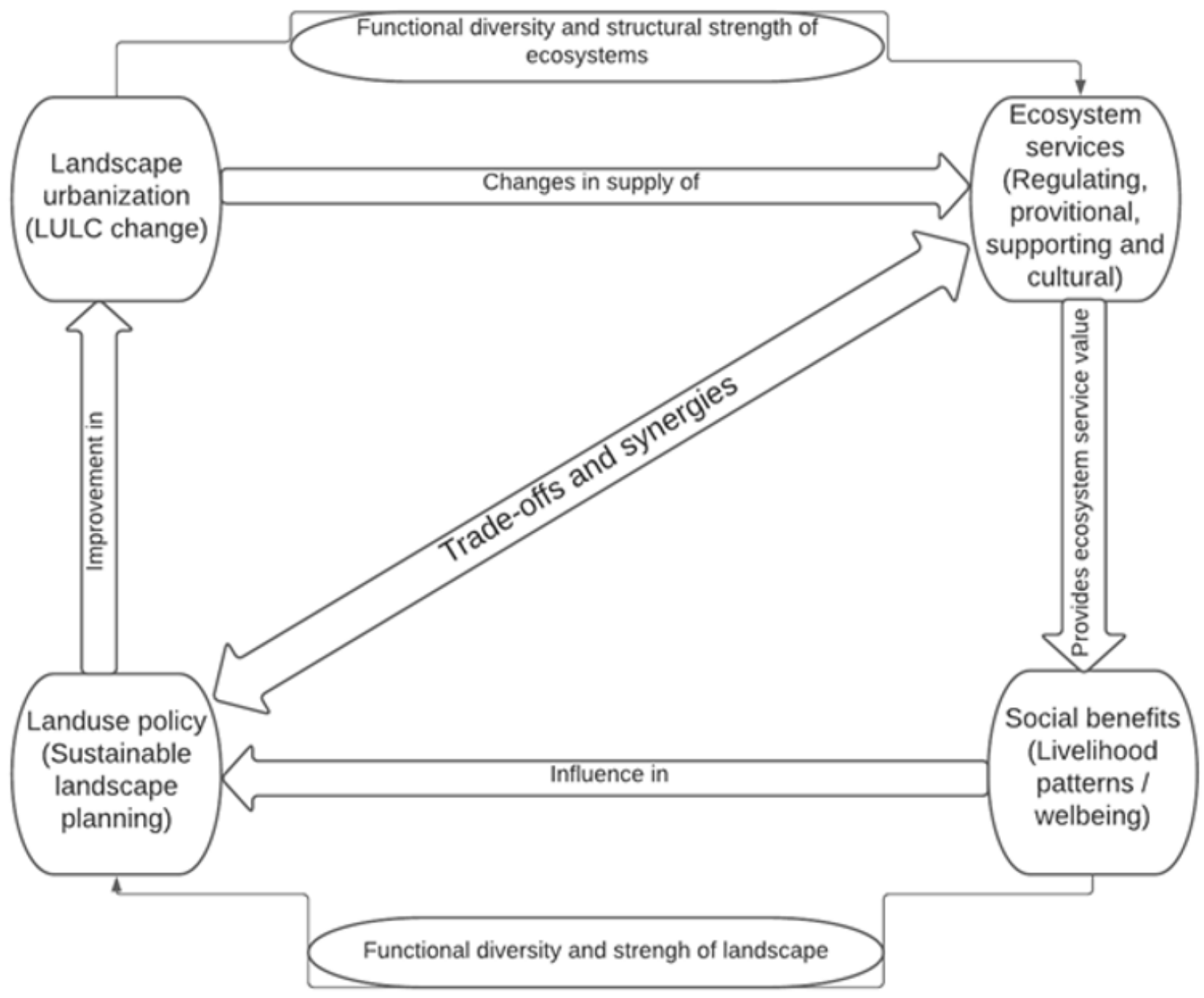

\section{Figure 9}

Trade-off analysis and synergies between environment and socio-economic goals 